\title{
Risk behavioral survey in the sample of Slovak adolescents
}

\author{
Babjakova $\mathrm{J}^{1}$, Vondrova $\mathrm{D}^{1}$, Jurkovicova $\mathrm{J}^{1}$, Samohyl $\mathrm{M}^{1}$, Filova $\mathrm{A}^{1}$, Janko $\mathrm{Z}^{1}$, Stefanikova $\mathrm{Z}^{1}$, \\ Hirosova $\mathrm{K}^{1}$, Weitzman $\mathrm{M}^{1,2}$, Argalasova $\mathrm{L}^{1}$ \\ Comenius University, Faculty of Medicine, Institute of Hygiene, Bratislava, Bratislava, Slovakia. \\ Lubica.argalasova@fmed.uniba.sk
}

\begin{abstract}
OBJECTIVE: The study was aimed to assess risky behavioral factors in the sample of Slovak adolescents. BACKGROUND: Health-risk behavior contributes to the leading causes of morbidity and mortality among youth and adults.

MATERIALS AND METHODS: The Youth and Parents Risk Factor Behavior Survey (YABS), based on bilateral US-Slovak project, is an ongoing cross-sectional school-based survey initiated in Bratislava as a model region. There were 798 questionnaires for students distributed; the response rate was $64 \%$. The sample involved 525 adolescents aged 15-19 years from eight selected secondary schools in Bratislava, $38 \%$ boys and $62 \%$ girls. More than $90 \%$ of fathers and mothers were employed, but some families nevertheless experienced a lack of finances (48.1\%), almost $70 \%$ of students were from complete families. RESULTS: The study revealed a very high prevalence of risky behavioral characteristics in this pilot sample of adolescents significantly related to age, gender, type of school, completeness of the family and lower parental education.

CONCLUSION: The most important health risk behaviors were identified (tobacco, alcohol, drug consumption, violence, risky sexual behavior, inadequate sleep, physical inactivity, and excessive IT devices use). Targeted intervention proposals will be suggested in future (Tab. 5, Ref. 42). Text in PDF www.elis.sk.

KEY WORDS: school-based survey, adolescents, risk factors, behavioral characteristics.
\end{abstract}

\section{Introduction}

Adolescence is the phase of life stretching between childhood and adulthood and it encompasses elements of biological growth and major social role transitions (1). It is a life phase, in which the opportunities for health are great and future patterns of adult health are established (2). In these developmental stages, profound physical, intellectual, emotional, psychological, and sexual changes occur (3). As in any age group, economic and social conditions influence adolescent health. Adolescence represents a good opportunity to promote good health, but also to improve inappropriate health (4).

Health-risk behaviors contribute to the leading causes of morbidity and mortality among youth and young adults in the United States associated with the leading causes of death among persons aged 10-24 years. In 2016, $74 \%$ of all deaths among persons aged

${ }^{1}$ Comenius University, Faculty of Medicine, Institute of Hygiene, Bratislava, Bratislava, Slovakia, and ${ }^{2}$ Department of Pediatrics, New York University, New York, USA

Address for correspondence: L. Argalasova, MD, PhD, MPH, Comenius University, Faculty of Medicine, Institute of Hygiene, Spitalska 24, SK81372 Bratislava, Slovakia.

Phone: +421.905209114

Acknowledgement: This manuscript was supported by the grants YABS (Youth and Parents Behavioral Survey in Slovakia) O-15-101-/0001-00.
10-24 years resulted from four major causes: motor vehicle crashes (22\%), other unintentional injuries (20\%), suicide (17\%), and homicide (15\%) (5). Among persons aged $\geq 25$ years, $54 \%$ of all deaths in the United States resulted from cardiovascular disease (31\%) and cancer (23\%), similar in Europe for people below 65 years of age (6). The results from the national YRBSS (Youth Risk Behavior Surveillance System) in 2017 indicated that many high school students are engaged in health-risk behaviors. These risk behaviors are established during childhood and adolescence and extend into adulthood (7). The majority of chronic noncommunicable diseases (NCD) have multifactorial etiology. It is important to identify the most prevalent risk factors, but also protective factors at a younger age to decrease the chance of developing NCD later in life. The current status and the trends in major modifiable risk factors reinforce the importance of the prevention, detection, and treatment of risk factors in reducing the burden of NCDs on individuals and society (8).

Although some studies documented the occurrence and relationship among some factors associated with an increased morbidity and mortality and their impact on health, the risk factors in the younger age groups are not well-studied in Slovakia.

The main aim of this study The Youth and Parents Risk Factor Behavior Survey in Slovakia (YABS) is to assess several behavioral factors in the sample of Slovak adolescents and adults (high school students and their parents or legal representatives) according to the model CDC surveys taking into account national 
specificities. The project will identify persons at risk and target the attention of teachers, researchers, policy makers and the general public on these issues.

\section{Methods}

The Youth and Parents Risk Factor Behavior Survey in Slovakia, an ongoing cross-sectional school-based survey of students and their parents or legal representatives has been initiated during the years 2015/2016 in Bratislava, the Slovak capital, as a model region. It originates from The Behavioral Risk Factor Surveillance System (BRFSS) and The Youth Risk Behavior Surveillance System (YRBSS), originally designed by CDC, Atlanta, USA $(9,10)$. The BRFSS was a random telephone survey of US state residents aged 18 and older with the primary focus on such behaviors that include sedentary behavior, physical activity; nutrition, safety (e.g. the use of seatbelts and helmets); using tobacco and alcohol; getting preventive medical care, etc. (9). The YRBSS was developed in 1990 monitoring six categories of priority health-risk behaviors among youth and young adults (aged 15-19 years) in public and private schools in the USA (10).

There were 2,384 questionnaires distributed in total ( 798 for students; 1,586 for parents), the response rates were $64 \%$ and $46 \%$ respectively. The sample involves 525 adolescents aged

Tab. 1. Characteristics of the students' sample $(n=525)$.

\begin{tabular}{|c|c|c|c|}
\hline Variable & & $\mathrm{N}^{*}$ & $\%$ \\
\hline \multirow{2}{*}{ Gender } & Boys & 199 & 38.0 \\
\hline & Girls & 324 & 62.0 \\
\hline \multirow{4}{*}{ Age groups } & $15-16 y$ & 106 & 20.5 \\
\hline & $16-17 y$ & 157 & 30.4 \\
\hline & $17-18 y$ & 119 & 23.0 \\
\hline & more than $18 \mathrm{y}$ & 135 & 26.1 \\
\hline \multirow{3}{*}{ Type of school } & Grammar schools & 210 & 40.0 \\
\hline & Secondary special schools & 186 & 35.4 \\
\hline & Vocational schools & 129 & 24.6 \\
\hline \multirow{2}{*}{ Nationality } & Slovak & 477 & 91.0 \\
\hline & Other & 47 & 9.0 \\
\hline \multirow{2}{*}{ Residence } & Urban & 306 & 58.5 \\
\hline & Rural & 211 & 41.5 \\
\hline \multirow{2}{*}{ Family } & Complete & 361 & 69.8 \\
\hline & Incomplete & 156 & 30.2 \\
\hline \multirow{2}{*}{ Siblings } & Yes & 425 & 82.0 \\
\hline & No & 93 & 18.0 \\
\hline \multirow{3}{*}{$\begin{array}{l}\text { Father's educational } \\
\text { level }\end{array}$} & Primary or vocational school & 130 & 27.1 \\
\hline & High school graduation & 206 & 43.0 \\
\hline & University degree & 143 & 29.9 \\
\hline \multirow{3}{*}{$\begin{array}{l}\text { Mother's educational } \\
\text { level }\end{array}$} & Primary or vocational school & 98 & 19.4 \\
\hline & High school graduation & 243 & 47.9 \\
\hline & University degree & 166 & 32.7 \\
\hline \multirow{2}{*}{ Employment of father } & Yes & 454 & 93.8 \\
\hline & No & 30 & 6.2 \\
\hline \multirow{2}{*}{ Employment of mother } & Yes & 472 & 91.3 \\
\hline & No & 45 & 8.7 \\
\hline \multirow{3}{*}{ Feeling lack of money } & Never & 220 & 43.1 \\
\hline & Sometimes & 246 & 48.1 \\
\hline & Still & 45 & 8.8 \\
\hline
\end{tabular}

"There are some data missing in each variable category.
15-19 years old from 8 selected secondary schools in Bratislava from total 101 secondary vocational and grammar schools - there were 22,723 students totally in Bratislava in the 1st January 2016. The separate questionnaires were sent home to parents (in total there were 178,290 adults 40-60 years old living in Bratislava out of 618,380 inhabitants in Bratislava agglomeration in the 1st January 2016).

Only the data from „The Questionnaire for Students“ are presented in this paper. It included questions on a residence, family, school, health and safety, habits and behavior, nutrition, body weight and height, lifestyle and physical activity. The special emphasis was paid to the use of selected telecommunication and other screen devices (TV, non-TV screen devices: PC, personal music players - PMP, mobile phones). From self-reported body weight and height data BMI (Body mass index) was calculated according to formula; BMI = weight $/$ height $^{2}\left(\mathrm{~kg} \cdot \mathrm{m}^{-2}\right)($ to evaluate overweight and obesity gender, and age specific percentile charts used for students under 18 years old and adult students were classified according to WHO BMI classification) (11).

There were $38 \%$ boys and $62 \%$ girls, $90.9 \%$ of Slovak nationality, the average age of students was $17.18 \pm 1$ years. Age categories were distributed evenly, with most students aged 16.1 to 17.0 years old $(30.4 \%)$. In the urban areas lived $58.5 \%$ of students, $69.8 \%$ of students were from the complete families and $82 \%$ had at least one sibling. Fathers and mothers of students completed mostly secondary education (43\%, $47.9 \%$ ); $29.9 \%$ of fathers and $32.7 \%$ of mothers had a university education. More than $90 \%$ of fathers and mothers were employed, but some families nevertheless experienced a lack of finances (48.1\%) (Tab. 1).

The survey was anonymous and voluntary, approved by the Ethical Committee of Faculty of Medicine Comenius University and University Hospital.

Statistical Package for Social Science (SPSS) version 25 was used for the statistical analysis. We used methods of descriptive and analytical statistics; the relations between categorical data were evaluated using bivariable analysis, contingency tables, and chi-square test. Statistical tests were two-sided at a significance level of $5 \%$.

\section{Results}

The occurrence of classical cigarettes smoking in the students' sample was $19.9 \%$, older students and students from vocational schools smoked significantly more. The experience with different forms of alternative tobacco products (ATP) (except electronic cigarettes - EC) had $63.1 \%$ of students, especially older ones. There were no differences in the experience with vaping EC among age groups - a very high percentage ( $>$ $40 \%$ ) in both groups (younger and older) (Tab. 2). Majority of students, who are current smokers, have tried to stop smoking (59.2\%: $54.4 \%$ boys, $64.2 \%$ girls). Only $12.5 \%$ would appreciate help from a professional with smoking cessation $(17.5 \%$ boys, $7.6 \%$ girls).

We confirmed differences between the smoking status and overall feeling of healthiness as well. From non-smokers, $88.2 \%$ 
Tab. 2. Selected behavioral characteristics in relation to age and gender in the sample of adolescents $(n=525)$.

\begin{tabular}{|c|c|c|c|c|c|c|c|c|}
\hline \multirow{3}{*}{ Variable } & & \multirow{2}{*}{ Total } & \multicolumn{2}{|c|}{ Gender } & \multicolumn{4}{|c|}{ Age group } \\
\hline & & & Boys & Girls & & Younger $^{\mathrm{a}}$ & Older $^{\mathrm{b}}$ & \\
\hline & & $\mathrm{N}^{*} / \%$ & $\mathrm{~N}^{*} / \%$ & $\mathrm{~N}^{*} / \%$ & $\mathrm{p}$-value & $\mathrm{N}^{*} / \%$ & $\mathrm{~N}^{*} / \%$ & $\mathrm{p}$-value \\
\hline \multirow{2}{*}{ Smoking } & yes & $102 / 19.9$ & $45 / 23.0$ & $57 / 18.1$ & \multirow[b]{2}{*}{ n.s. } & 28/11.4 & $74 / 28.5$ & \multirow{2}{*}{$<0.001$} \\
\hline & no & $411 / 80.1$ & $151 / 77$ & $258 / 81.9$ & & $218 / 88.6$ & $186 / 71.5$ & \\
\hline \multirow{2}{*}{ Experience with ATP } & yes & $260 / 63.1$ & $104 / 67.5$ & $156 / 60.9$ & \multirow{2}{*}{ n.s. } & $114 / 57.0$ & $145 / 69.4$ & \multirow{2}{*}{$<0.01$} \\
\hline & no & $152 / 36.9$ & $50 / 32.5$ & $100 / 39.1$ & & $86 / 43.0$ & $64 / 30.6$ & \\
\hline \multirow{2}{*}{ Experience with EC } & yes & $209 / 44.3$ & $91 / 49.7$ & $117 / 40.8$ & \multirow{2}{*}{ n.s. } & $93 / 40.6$ & $115 / 48.3$ & \multirow{2}{*}{ n.s. } \\
\hline & no & $263 / 55.7$ & $92 / 50.3$ & $170 / 59.2$ & & $136 / 59.4$ & $123 / 51.7$ & \\
\hline \multirow{2}{*}{ Alcohol consumption ${ }^{c}$} & yes & $306 / 60.1$ & $119 / 61.0$ & $186 / 59.4$ & \multirow{2}{*}{ n.s. } & $114 / 46.5$ & 189/73.3 & \multirow{2}{*}{$<0.01$} \\
\hline & no & $203 / 39.9$ & $76 / 39.0$ & $127 / 40.6$ & & $131 / 53.5$ & $69 / 26.7$ & \\
\hline \multirow{2}{*}{ Drunkenness } & yes & $277 / 54.3$ & $51 / 26.0$ & $65 / 20.3$ & \multirow{2}{*}{ n.s. } & $102 / 41.5$ & $172 / \mathbf{6 6 . 9}$ & \multirow{2}{*}{$<0.05$} \\
\hline & no & $233 / 45.7$ & $145 / 74.0$ & $255 / 79.7$ & & $144 / 58.5$ & $85 / 33.1$ & \\
\hline \multirow{2}{*}{ Experience with drugs } & yes & $139 / 27.3$ & $59 / 30.3$ & $79 / 25.2$ & \multirow{2}{*}{ n.s. } & 49/19.9 & $88 / 34.2$ & \multirow{2}{*}{$<0.001$} \\
\hline & no & $371 / 72.7$ & $136 / 69.7$ & $234 / 74.8$ & & $197 / 80.1$ & $169 / 65.8$ & \\
\hline \multirow{2}{*}{ Sexual intercourse } & yes & $195 / 39.0$ & $77 / 40.7$ & $117 / 37.9$ & \multirow{2}{*}{ n.s. } & $41 / \mathbf{1 6 . 7}$ & $152 / 61.3$ & \multirow{2}{*}{$<0.001$} \\
\hline & no & $305 / 61.0$ & $112 / 59.3$ & $192 / 62.1$ & & $204 / 83.3$ & $96 / 38.7$ & \\
\hline \multirow{2}{*}{ Listening to $\mathrm{PMP}^{\mathrm{d}}$} & yes & $457 / 90.1$ & $163 / 85.8$ & 292/92.7 & & $227 / 92.3$ & $225 / 88.6$ & \\
\hline & no & $50 / 9.9$ & $27 / 14.2$ & $23 / 7.3$ & $<0.05$ & $19 / 7.7$ & $29 / 11.4$ & n.s. \\
\hline Listening to PMP & $\leq 200$ & $210 / 49.8$ & $70 / 47.0$ & $140 / 51.5$ & & $116 / 54.5$ & $93 / 45.1$ & \\
\hline$(\mathrm{min} /$ week $)$ & $>200$ & $212 / 50.2$ & $79 / 53.0$ & $132 / 48.5$ & n.s. & $97 / 45.5$ & $113 / 54.9$ & n.s. \\
\hline & yes & $396 / 77.8$ & $153 / 79.7$ & $241 / 76.5$ & & 201/81.7 & $188 / 73.4$ & \\
\hline Attending PE & no & $113 / 22.2$ & $39 / 20.3$ & $74 / 23.5$ & n.s. & $45 / 18.3$ & $68 / 26.6$ & $<0.05$ \\
\hline Doing sports on regular & yes & $318 / 63.1$ & $137 / 72.1$ & $180 / 57.5$ & $<001$ & $159 / 64.9$ & $156 / 61.7$ & \\
\hline basis & no & $186 / 36.9$ & $53 / 27.9$ & $133 / 42.5$ & $<0.01$ & $86 / 35.1$ & $97 / 38.3$ & n.s. \\
\hline Sleeping time & $\geq 7$ & $348 / 68.1$ & $138 / 71.9$ & $209 / 65.9$ & & $191 / 77.0$ & $154 / 60.2$ & \\
\hline (Mo-Fri) & $<7$ & $163 / 31.9$ & $54 / 28.1$ & $108 / 34.1$ & n.s. & $57 / 23.0$ & $102 / 39.8$ & $<0.001$ \\
\hline Sleeping time & $\geq 7$ & $490 / 96.6$ & $179 / 94.7$ & $309 / 97.8$ & & $242 / \mathbf{9 8 . 4}$ & 241/94.9 & $<005$ \\
\hline (Sat-Sun) & $<7$ & $17 / 3.4$ & $10 / 5.3$ & $7 / 2.2$ & II.s. & 4/1.6 & $13 / 5.1$ & -0.05 \\
\hline PC usage daily & $<3$ & $205 / 40.4$ & $80 / 42.1$ & $123 / 38.9$ & & $114 / 46.0$ & $87 / 34.4$ & $<001$ \\
\hline (Mo-Fri) & $\geq 3$ & $303 / 59.6$ & $110 / 57.9$ & $193 / 61.1$ & n.s. & $134 / 54.0$ & $166 / 65.6$ & $<0.01$ \\
\hline PC usage daily & $<3$ & $139 / 27.9$ & $43 / 23.5$ & $95 / 30.4$ & & $72 / 29.9$ & $66 / 26.4$ & \\
\hline$\underline{\text { (Sat-Sun) }}$ & $\geq 3$ & $359 / 72.1$ & $140 / 76.5$ & $218 / 69.6$ & n.s. & $169 / 70.1$ & $184 / 73.6$ & n.s. \\
\hline TV watching & $<3$ & $462 / 91.1$ & $168 / 88.0$ & $292 / 93.0$ & & $223 / 90.3$ & $232 / 91.7$ & \\
\hline (Mo-Fri) & $\geq 3$ & 45/8.9 & $23 / 12.0$ & $22 / 7.0$ & n.s. & $24 / 9.7$ & $21 / 8.3$ & n.s. \\
\hline TV watching & $<3$ & $371 / 73.8$ & $141 / 74.6$ & $228 / 73.1$ & & $171 / 70.4$ & $195 / 77.1$ & \\
\hline (Sat-Sun) & $\geq 3$ & $132 / 26.2$ & $48 / 25.4$ & $84 / 26.9$ & n.s. & $72 / 29.6$ & $58 / 22.9$ & n.s. \\
\hline
\end{tabular}

*There are some data missing in each variable category. ${ }^{\mathrm{a}} \leq 16$ years; ${ }^{\mathrm{b}}>16$ years; ${ }^{\mathrm{c}}$ at least $1 / \mathrm{month}^{\mathrm{d}}{ }^{\text {at }}$ least $1 /$ week; ATP - alternative tobacco products; EC - electronic cigarettes; PMP - personal music players; PE - physical education; n.s. - not significant

of students feel well, compared to $69.3 \%$ of smokers ( $<<0.001$ ), $81.2 \%$ of nonsmokers felt well at school comparing to only 60.4 $\%$ of smokers. More than $60 \%$ of students were drinking alcohol at least once in the last month, $19.9 \%$ more than 3 times a month, significantly increasing with age and more from incomplete families (Tabs 2 and 4).

Drunkenness was not rare $(54.3 \%$ of students have been drunk during the previous month), it was more apparent among students from higher grades, vocational schools and incomplete families (Tabs 2, 3 and 4). Older students and students from vocational schools had also more experiences with different kinds of drugs (27.3\% totally) (Tabs 2, 3 and 4). The percentage of sexually active high school students in our sample was $39.0 \%$. More sexual experience had significantly older students, students from vocational schools, from incomplete families, and from families with lower parental education (Tabs 2, 3 and 4). Only $77.8 \%$ of students exercise regularly on compulsory Physical Education
(PE). Absence from PE was more prevalent in older students and students from vocational schools (Tabs 2 and 3). Only $63.1 \%$ of students were doing sports on a regular basis during their spare time. Lack of sports activities was dominant among female students, students from vocational schools and students from less educated families (lower parental education) (Tabs 3 and 4). The average time spend with sedentary activities was 10.53 hours/day among boys and 8.76 among girls.

The percentage of students using PC over 3 hours daily was $59.6 \%$ Monday-Friday and $72 \%$ Saturday and Sunday, watching TV more than 3 hours was $8.9 \%$ Monday-Friday and $26.2 \%$ Saturday and Sunday (Tab. 1). $90.9 \%$ of students listened to personal music players (PMP) on average 405 minutes and used mobile phone 384 minutes per week, significantly more girls. About $50 \%$ of students were listening to PMP more than 200 minutes a week. Those students had a worse lifestyle as well. The tinnitus among them was also present $(\mathrm{p}<0.01)$. They smoked, drunk al- 
Tab. 3. Selected behavioral characteristics in relation to type of school in the sample of adolescents $(n=525)$.

\begin{tabular}{|c|c|c|c|c|c|}
\hline \multirow{2}{*}{ Variable } & & \multirow{2}{*}{$\begin{array}{c}\text { Grammar school } \\
\mathrm{N}^{*} / \%\end{array}$} & \multirow{2}{*}{$\frac{\text { Special school }}{\mathrm{N}^{*} / \%}$} & \multicolumn{2}{|l|}{ Vocational school } \\
\hline & & & & $\mathrm{N}^{*} / \%$ & p-value \\
\hline \multirow{2}{*}{ Smoking } & yes & $30 / \mathbf{1 4 . 6}$ & $30 / \mathbf{1 6 . 5}$ & 42/33.6 & \multirow{2}{*}{$<0.001$} \\
\hline & no & $176 / 85.4$ & $152 / 83.5$ & $83 / 66.4$ & \\
\hline \multirow{2}{*}{ Experience with ATP } & yes & $103 / 60.9$ & $87 / 62.6$ & $70 / 67.3$ & \multirow{2}{*}{ n.s. } \\
\hline & no & $66 / 39.1$ & $52 / 37.4$ & $34 / 32.7$ & \\
\hline Experience with EC & yes & $76 / 39.8$ & $72 / 44.4$ & $61 / 51.3$ & n.s. \\
\hline \multirow{2}{*}{ Alcohol consumption ${ }^{\mathrm{a}}$} & yes & $115 / 55.8$ & $110 / 62.5$ & $81 / 63.8$ & \multirow[b]{2}{*}{ n.s. } \\
\hline & no & $91 / 44.2$ & $66 / 37.5$ & $46 / 36.2$ & \\
\hline \multirow{2}{*}{ Drunkenness } & yes & $104 / \mathbf{5 0 . 5}$ & $92 / \mathbf{5 1 . 7}$ & $81 / 64.3$ & \multirow{2}{*}{$<0.05$} \\
\hline & no & $102 / 49.5$ & $86 / 48.3$ & $45 / 35.7$ & \\
\hline \multirow{2}{*}{ Experience with drugs } & yes & $61 / 29.8$ & $34 / \mathbf{1 9 . 0}$ & $44 / 34.9$ & \multirow{2}{*}{$<0.01$} \\
\hline & no & $144 / 70.2$ & $145 / 81.0$ & $82 / 65.1$ & \\
\hline Sexual intercourse & yes & $48 / 23.4$ & $69 / 39.7$ & $78 / 64.5$ & $<0.001$ \\
\hline \multirow{2}{*}{ Listening to $\mathrm{PMP}^{\mathrm{b}}$} & yes & $187 / 90.3$ & $164 / 91.6$ & $106 / 87.6$ & \multirow{2}{*}{ n.s. } \\
\hline & no & $20 / 9.7$ & $15 / 8.4$ & $15 / 12.4$ & \\
\hline \multirow{2}{*}{ Listening to PMP (min/week) } & $\leq 200$ & $84 / 48.6$ & $77 / 52.0$ & $49 / 48.5$ & \multirow{2}{*}{ n.s. } \\
\hline & $>200$ & $89 / 51.4$ & $71 / 48.0$ & $52 / 51.5$ & \\
\hline \multirow{2}{*}{ Attending PE } & yes & $179 / 86.5$ & $128 / 71.5$ & $89 / 72.4$ & \multirow{2}{*}{$<0.001$} \\
\hline & no & $28 / 13.5$ & $51 / 28.5$ & $34 / 27.6$ & \\
\hline \multirow{2}{*}{ Doing sports on regular basis } & yes & $157 / 76.2$ & $100 / \mathbf{5 6 . 5}$ & $61 / 50.4$ & \multirow{2}{*}{$<0.001$} \\
\hline & no & $49 / 23.8$ & $77 / 43.5$ & $60 / 49.6$ & \\
\hline \multirow{2}{*}{$\begin{array}{l}\text { Sleeping time daily } \\
\text { (Mo-Fri)/hours }\end{array}$} & $\geq 7$ & $149 / 72.0$ & $122 / 67.8$ & $77 / 62.1$ & \multirow{2}{*}{ n.s. } \\
\hline & $<7$ & $58 / 28.0$ & $58 / 32.2$ & $47 / 37.9$ & \\
\hline & $\geq 7$ & 201/98.5 & $175 / \mathbf{9 7 . 8}$ & $114 / 91.9$ & \\
\hline (Sat-Sun)/hours & $<7$ & $3 / 1.5$ & $4 / 2.2$ & $10 / 8.1$ & $<0.01$ \\
\hline PC usage daily & $<3$ & $93 / 45.6$ & $70 / 38.9$ & $42 / 33.9$ & \\
\hline (Mo-Fri)/hours & $\geq 3$ & $111 / 54.4$ & $110 / 61.1$ & $82 / 66.1$ & n.s. \\
\hline TV watching daily & $<3$ & $189 / 91.7$ & $164 / 92.1$ & $109 / 88.6$ & \\
\hline (Mo-Fri)/hours & $\geq 3$ & $17 / 8.3$ & $14 / 7.9$ & $14 / 11.4$ & n.s. \\
\hline TV watching daily & $<3$ & $158 / 77.5$ & $123 / 68.7$ & $90 / 75.0$ & \\
\hline (Sat-Sun)/hours & $\geq 3$ & $46 / 22.5$ & $56 / 31.3$ & $30 / 25.0$ & n.s. \\
\hline
\end{tabular}

${ }^{*}$ There are some data missing in each variable category. ${ }^{a}$ at least $1 /$ month; ${ }^{\mathrm{b}}$ at least $1 /$ week; ATP - alternative tobacco products; EC - electronic cigarettes; PMP - personal music players; PE - physical education; n.s. - not significant

cohol, used drugs and experienced with ATP significantly more than students listening PMP less than 200 minutes a week. In this group, we observed a higher percentage of PC use especially during Monday through Friday $(\mathrm{p}<0.01)(12)$.

More than $31.9 \%$ of students did not sleep enough, sleeping time on Monday-Friday less than 7 hours was more prevalent among older students and students from less educated families (lower parental education) (Tabs 2, 3, 4). During weekends students slept much longer, only $3.4 \%$ of them slept less than 7 hours on Saturday-Sunday. Students from vocational schools slept significantly less than students from grammar and special schools (Tab. 3).

The percentage of students exposed to physical violence was $22.4 \%$ and $11.8 \%$ admitted that they humiliated, amused or physically attacked their classmates.

The occurrence of overweight/obesity according to BMI differed between boys $28.6 \%$ and girls $11.6 \%(\mathrm{p}<0.001)$ and did not significantly vary with age. There were noteworthy gender differences: among obese boys, less than half felt obese, while $77.1 \%$ of obese girls felt obese ( $\mathrm{p}<0.001), 18 \%$ of normal BMI-children reported dieting in the previous year vs $27.3 \%$ among obese children $(p=0.052)$. Obese students reported consuming more energy drinks $(p=0.023)$, exercised less at school $(p=0.016)$, and were participating in fewer extracurricular physical activities $(p=0.10)$. Clear gender differences were apparent, with a tendency among boys to be overweight. Poor body image and dieting behavior were more prevalent among girls (13).

From the bivariable analysis, we can conclude that the majority of risky behaviors are related to age. Especially high and significant odds ratios were calculated for smoking (OR 3.10 (1.92-4.99)), alcohol consumption (OR 3.15 (2.17-4.57)) and sexual intercourse (OR 7.88 (5.17-12.01)). Lower parental education was significantly related to lack of sleep and lack of sport activities and to high sexual intercourse, and father's low educa- 


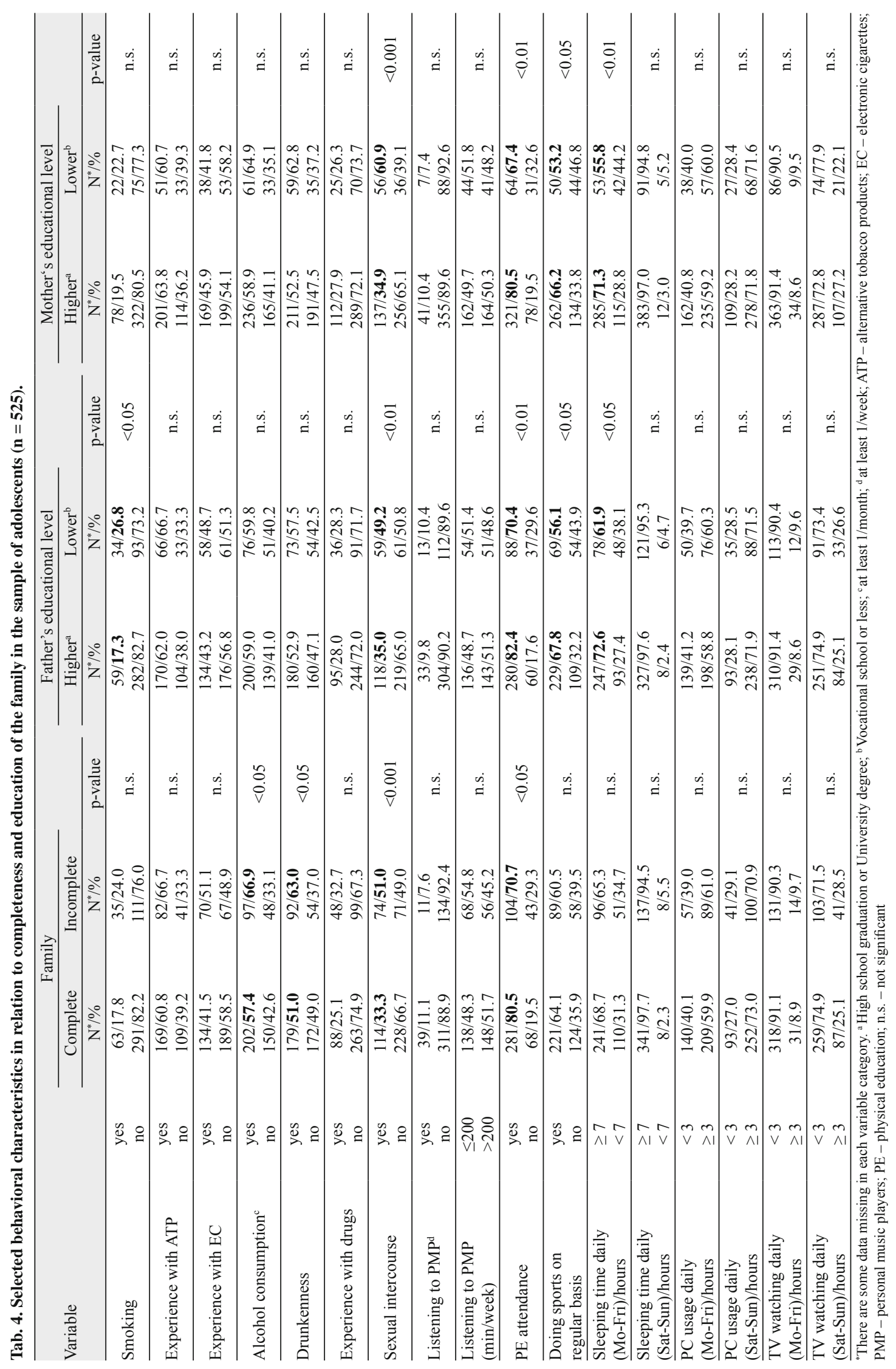




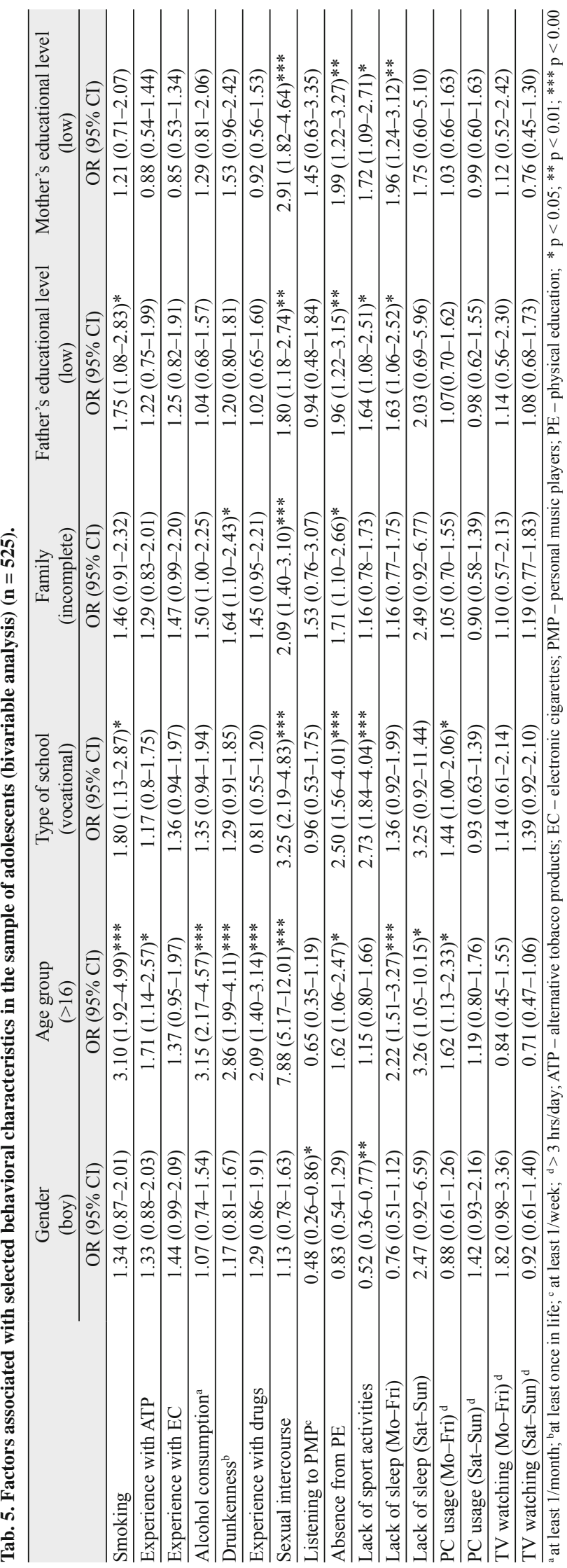

tion also for the smoking prevalence of adolescents. Students from vocational schools did fewer sports, but were more sexually active (OR 3.25 (2.19-4.83)) and smoked more (OR 1.80 (1.13-2.87)). Gender differences were not significant in many risky behaviors. Girls listened to PMP more often (OR 0.48 (0.26-0.86)) and did fewer sports (OR $0.52(0.36-0.77)$ ). Family incompleteness played a role as well. Adolescents from incomplete families had more experiences with drunkenness during the previous month (OR 1.64 (1.10-2.43)), they were more sexually active (OR 2.09 $(1.40-3.10))$ and attended less frequently compulsory PE (OR 1.7 (1.10-2.66)) (Tab. 5).

\section{Discussion}

In this study, the most important health risk behaviors in Bratislava students' sample were identified (tobacco, alcohol, drugs consumption, violence, risky sexual behavior, inadequate sleep, and physical inactivity and the excessive use of IT devices (PC, PMP, TV, etc.).

Risky behaviors in adolescence affect the overall health status, well-being and the healthy development of individuals' personality (14). Inappropriate lifestyle, especially incorrect eating habits and lack of physical activity, can negatively affect health and cause an early onset of chronic non-communicable diseases, leading causes of morbidity and mortality $(11,15,16)$.

In our study, we found a very high occurrence of several risky behavioral characteristics compared to the other studies.

According to BRFSS US, adolescents smoke less (15.7\%), drink alcohol less $(50.8 \%)$, they are less sexually active (34\%), but watch more TV (32\%), consume more soda several times daily $(27 \%)$ and admit more physical violence in schools $(25 \%)(17,9)$.

Results from the national YRBSS in 2017 indicated that many high school students were engaged in health-risk behaviors associated with the leading causes of death among persons aged 10-24 years in the United States. During the 12 months before the survey, $19.0 \%$ had been bullied on school property and $7.4 \%$ had attempted suicide, $39.5 \%$ of students had a sexual intercourse and $9.7 \%$ had a sexual intercourse with four or more persons during their life. YRBSS also indicated many high school students were engaged in behaviors associated with chronic diseases, such as: cardiovascular disease, cancer, and diabetes. Nationwide, $8.8 \%$ of high school students smoked cigarettes and $13.2 \%$ had used an electronic vapor product on at least 1 day, $29.8 \%$ reported current alcohol use. Forty-three percent of students played video or computer games or used a personal computer for 3 or more hours per day on an average school day, not for school work and 15.4 $\%$ had not been physically active for a total of at least 60 minutes on at least one day (18).

In nationally representative yearly surveys of United States 8th, 10th, and 12th graders 1991-2016 ( $\mathrm{n}=1.1$ million), psychological well-being (measured by self-esteem, life satisfaction, and happiness) suddenly decreased after 2012. Adolescents, who spent more time on electronic communication and screens (e.g., social media, the Internet, texting, gaming) and less time on nonscreen activities (e.g., in-person social interaction, sports/exercise, 
homework, attending religious services) had a lower psychological well-being (19).

Tobacco product use is often started and established primarily during adolescence. Tobacco kills more than 8 million people each year and it remains a major risk factor for cardiovascular disease and the leading preventable cause of death worldwide (20). Both prevention of smoking initiation among youth and smoking cessation among established smokers are key for reducing smoking prevalence and the associated negative health consequences (21). In the last release (2017/2018) of collaborative WHO survey Health Behaviour in School-aged Children (HBSC), which collected data of 11-, 13- and 15-year-old boys and girls from 42 countries in Europe and North America including Slovakia, it was found that an early initiation of smoking and alcohol abuse is relatively common in Slovakia. At the age of 15 years, almost $39 \%$ of girls and $40 \%$ of boys have the first experience with tobacco smoke, and $23 \%$ resp. $21 \%$ of them have been smoking during the previous 30 days. Even if the trends of experience with classical cigarettes seems to be declining in this study (from $63 \%$ in 2010 to $48 \%$ in 2014 and $40 \%$ in 2018 among 15-year-old boys) the prevalence is still very high (22). According to data from GYTS (Global Youth Tobacco Survey) in 2016, there were 21.6 \% current tobacco smokers and $8.0 \%$ of current electronic cigarette users among 13-15-years old students (23). The new alternative tobacco products (electronic cigarettes, hookahs, cigars, etc.), are becoming more and more popular among adolescents and represent a growing problem $(24,25)$.

Given the increasing popularity of electronic cigarettes and recommendation of harm reduction strategy, it is imperative to evaluate the health risks of e-cigarettes, including the effects of their ingredients, especially nicotine and flavorings. An acute exposure to flavored e-liquids or e-cigarette use exacerbates endothelial dysfunction, which often precedes cardiovascular diseases (26). In our study, the experience with different forms of alternative tobacco products (ATP) (except electronic cigarettes - EC) had $63.1 \%$ of students and more than $40 \%$ of students had an experience with vaping EC. Alcohol is one of the substances with addictive potential most commonly used by adolescents. Drinking during adolescence, which includes early initiation, frequent consumption and drunkenness, brings negative consequences for young people's psychological, social and physical health (27). According to the results from the latest HBSC study, almost 16-17 $\%$ of 15 -years old children have been drunk during the previous month, compared to every second student from our study (22).

Slovak children spent nowadays almost all afternoon with sedentary activities. Such manner negatively influences physical fitness compared to previous generations. Daily recommended physical activity for children is 90 minutes of moderate intensity or 60 minutes of moderate to vigorous intensity (28). From our sample, every fourth student is not exercising regularly on compulsory PE, and students spent with sedentary activities almost 10 hours. In the previous HBSC study, $46 \%$ of school children spent two or three hours daily watching TV $(29,30)$.

In the integrated review from Brazilian adolescents, where thirty-seven studies were analyzed, with a predominance of risky sexual behavior, tobacco use, and violent behavior, it was found that advancing age favored unprotected sex, alcohol and tobacco use. Influence of family and friends was related to smoking and alcohol consumption. Males were more involved in situations of violence and the female gender was associated with physical inactivity. Belonging to a lower economic class was related to unprotected sex, physical inactivity, unhealthy dietary behaviors, and violence (31).

Sufficient sleep is needed for the healthy development of children, maintenance and development of their physical and mental health. According to the recommendations of the American Academy of Sleep Medicine, children aged 13-18 years old should sleep regularly $8-10$ hours (32). In the latest HBSC study, the average sleeping time was 7.68 hours for boys and 7.61 hours for girls (33). In our sample, there were no gender differences in the sleeping time, but older students, students from vocational schools and from less educated families slept less. More than $31.9 \%$ of students did not sleep enough (less than 7 hours during Monday-Friday). During weekends they slept much longer (96.6 $\%$ of students slept seven hours or more) (Tab. 3).

Obesity is associated with a poor health-related quality of life. The present obesity epidemic in childhood will manifest with deleterious consequences in future, when adolescents reach adulthood (34). In our adolescent sample, the occurrence of overweight/obesity according to self-reported BMI differed between boys and girls. Almost every third boy was overweight/obese, and around $10 \%$ of girls were overweight/obese. In the recent study of Neermark et al, self-reported height and weight highly correlated with a physical measurement of height and weight (35). There are multiple studies about obesity and relations with different risk factors. According to Cespedes Feliciano et al, longer sleep duration and a higher sleep efficiency were associated with a more favorable cardiometabolic profile in early adolescence, independent of other obesity-related behaviors (36). Jong-Hyuck concluded that both smoking frequency and cigarette consumption had positive effects with regard to weight loss in adolescents. However, because smoking has negative side effects on general health, including an increase in abdominal fat and morbidity rates of obesity-related diseases, they recommend that adolescents should not smoke (37). In obese individuals, complex management of obesity should be applied (38). Generally, it is accepted that exercise plus food restriction is more effective than either therapy alone (39). Prevention is thus essential even before the overweight sets in according to specific individual needs. There are multiple reports that unequivocally associate overweight and obesity with an impaired health, related to hypertension, cardiovascular disease and type 2 diabetes (34). According to the study of Hujova and Lesniakova, the higher presence of obesity, hypertension, positive cardiovascular disease family history and poor lifestyle factors (cigarette smoking, physical inactivity, stress, and low socioeconomic status) were found in urban compared to rural children and adolescents (40). In the study by Schusterova et al, focused on the consequences of obesity, they found that in obese and overweight children, the signs of early myocardial damage, both structural and functional, were detectable mainly as the alteration of the left ventricular diastolic 
function, despite preserved global systolic function and these changes seemed to be intensified by the severity of obesity (41).

Our study revealed a very high occurrence of PMP listening and mobile phone use, especially in girls. About $50 \%$ of students are listening to PMP more than 200 minutes a week. Those students had a bad lifestyle and tinnitus was also present. In the Spanish study, the frequency of cordless phone calls, mobile phone dependency, and tablet use was related to an increase of subjective and objective sleep problems in adolescents (42).

This finding is very important and needs more investigation, because this issue was not addressed in YRBSS or in the HBSC study either.

\section{Conclusion}

Our study revealed a very high prevalence of risky behavioral characteristics among the students of the pilot sample of adolescents - high school students in the Slovakian capital, Bratislava, the model region. Some of those behavioral characteristics were significantly related to age, gender, type of school, completeness of the family and parental education. This is a comprehensive study, based on a combination of two validated studies. Parents were directly involved in the study, what makes challenges for the analysis and for future prevention and intervention. The resulting data from this study will be used to create preventive measures to protect and promote the health of children and youth.

\section{References}

1. Sawyer SM, Azzopardi PS, Wickremarathne D, Patton GC. The age of adolescence. Lancet Child Adolesc Health 2018; 2 (3): 223-228.

2. Center for Disease Control and Prevention. Division of Adolescent and School Health. 2016. https://www.cdc.gov/healthyyouth/about/pdf/ strategic_plan/dash_strategic_pla n.pdf

3. Sawyer SM, Afifi RA, Bearinger LH, Blakemore SJ, Dick B, Ezeh AC, Patton GC. Adolescence: a foundation for future health. Lancet 2012; 379 (9826): 1630-1640.

4. Reavley N, Patton GC, Sawyer SM, Kennedy E, Azzopardi P. Health and Disease in Adolescence. 239-252. In: Bundy DAP, Silva N, Horton S, Jamison DT, Patton GC (Eds). Child and Adolescent Heatlh and Development. Washington, DC: World Bank Group, 2017.

5. Center for Disease Control and Prevention. The underlying cause of death, 1999-2016. Multiple causes of death files, 1999-2016. 2017. https://wonder.cdc.gov/ucd-icd10.html

6. Eurostat. Causes of death statistics. 2018. https://ec.europa.eu/eurostat/statistics-explained/index.php/Causes_of_death_statistics\#Causes_ of_death_in_2015_of_people_below_65_years_of_age

7. Kann L, McManus T, Harris WA et al. Youth Risk Behavior Surveillance - United States, 2017. MMWR Surveill Summ 2018; 67 (8): 1-114.

8. Kim HCh, Oh SM. Noncommunicable Diseases: Current Status of Major Modifiable Risk Factors in Korea. J Prev Med Public Health 2013; 46 (4): 165-172.

9. Xu F, Mawokomatanda T, Flegel D et al. Surveillance for certain health behaviors among states and selected local areas - Behavioral Risk
Factor Surveillance System, United States, 2011. MMWR Surveill Summ 2014; 63 (9): 1-149.

10. Kann L, Kinchen S, Shanklin SL et al. Youth risk behavior surveillance - the United States, 2013. MMWR Suppl 2014; 63 (4): 1-168.

11. Vondrova D, Argalasova L, Babjakova J et al. Ukazovatele zivotneho stylu adolescentov (projekt YABS). 257-262. In: Hudeckova H, Jakusova $\mathrm{V}$, Svihrova V, Baska T (Eds). Aktualne problemy verejneho zdravotnictva vo vyskume a praxi IV. Martin: Jesseniova lekarska fakulta Univerzity Komenskeho v Martine, 2019.

12. Argalasova L, Vondrova D, Babjakova J et al. Behavioural, Psychosocial and Life-style Risk Factors in a Sample of Slovak Adolescents. J Infec Dis Treat 2019; 5: 36.

13. Babjakova J, Sevcikova L, Vondrova D et al. Nutritional status of Slovak students and selected behavioral risk factors - results from YABS Eur J Public Health 2018; 28 (Suppl 4): 491.

14. Bozzini AB, Rocha R, Munhoz TN, Santos IS, Barros AJD, Matijasevich A. Prevalence And Early Life Factors Associated With Risk Behaviors In Adolescence: A Population-Based Cohort Study. J Adolesc Health 2019; 64 (2): S72-S73.

15. Cunningham SA, Kramer MR, Narayan KM. Incidence of childhood obesity in the United States. N Engl J Med 2014; 370 (17): 1660-1661.

16. Kimakova T. Sledovanie vybranych faktorov zivotneho stylu vysokoskolakov. Kosice: Lekarska fakulta Univerzity Pavla Jozefa Safarika v Kosiciach, 2018: 109.

17. Argalasova L, Vondrova D, Babjakova J et al. Pouzivanie vybranych informacnych technologii vo vztahu k zivotnemu stylu adolescentov v projekte YABS 9-16. In: Hudeckova H, Jakusova V, Svihrova V, Baska $\mathrm{T}$ (Eds). Aktualne problemy verejneho zdravotnictva vo vyskume a praxi IV. Martin: Jesseniova lekarska fakulta Univerzity Komenskeho v Martine, 2019.

18. Center for Disease Control and Prevention. Youth Risk Behavior Survey. Data Summary \& Trends Report 2007-2017. 2018. https://www. cdc.gov/healthyyouth/ data/yrbs/pdf/trendsreport.pdf

19. Twenge JM, Martin GN, Campbell WK. Decreases in psychological well-being among American adolescents after 2012 and links to screen time during the rise of smartphone technology. Emotion 2018; 18 (6): 765-780.

20. World Health Organization. Tobacco. 2019. https://www.who.int/ news-room/fact-sheets/detail/tobacco

21. Centers for Disease Control and Prevention. The Health Consequences of Smoking - 50 Years of Progress. A Report of the Surgeon General. Atlanta (GA): Centers for Disease Control and Prevention: 2014.

22. Madarasova Geckova A, Bakalar P, Baska T et al. Socialne determinanty zdravia skolakov. Bratislava: Urad verejneho zdravotnictva SR, 2019: 401.

23. Baska T, Kollarova J. GYTS Slovakia 2016 Country Report. 2016. https://www.jfmed.uniba.sk/fileadmin/jlf/Pracoviska/ustav-verejnehozdravotnictva/GYTS/GYTS_Slovakia_Country_Report_2016.pdf

24. Babjakova J, Argalasova L, Vondrova D, Filova A, Kachutova I, Jurkovicova J. Alcohol consumption and smoking status in Slovak adolescents. Nepegeszsegugy 2019; 97 (2): 261-262.

25. Babjakova J, Vondrova D, Sevcikova L, Filova A, Jurkovicova J, Argalasova L, Weitzman M. Smoking in the sample of Slovak adolescents - results from the YABS study. In: Bauld L. (Eds). Society for Research on Nicotine \& Tobacco. Munchen: SRNT, 2018. 
26. Lee WH, Ong SG, Zhou Y et al. Modeling Cardiovascular Risks of E-Cigarettes With Human-Induced Pluripotent Stem Cell-Derived Endothelial Cells. J Am Coll Cardiol 2019; 73 (21): 2722-2737.

27. Inchley J, Currie D, Vieno A et al. Adolescent alcohol-related behaviours: trends and inequalities in the WHO European Region, 2002-2014. Copenhagen: World Health Organization: 2018.

28. Bielik V, Hamar D, Penesova A, Babjakova J, Antala B, Labudova J, Kovacs L. Odporucania pre pohybovu aktivitu deti a mladeze na Slovensku (6-18 rokov). Ces-slov Pediat 2017; 72 (6): 377-381.

29. Madarasova Geckova A, Baska T, Baskova $M$ et al. Narodna sprava o zdravi a so zdravim suvisiacom spravani 11, 13, 15-rocnych skolakov. Bratislava: World Health Organization (Country Office in Slovakia), 2015: 267.

30. Inchley J, Currie D, Young T et al. Growing up unequal: gender and socioeconomic differences in young people'shealth and well-being. Copenhagen: World Health Organization: 2016.

31. Moura LR, Torres LM, Cadete MMM, Cunha CF. Factors associated with health risk behaviors among Brazilian adolescents: an integrative review. Rev Esc Enferm USP 2018; 52: e03304.

32. Paruthi S, Brooks LJ, D’Ambrosio C et al. Recommended Amount of Sleep for Pediatric Populations: A Consensus Statement of the American Academy of Sleep Medicine. J Clin Sleep Med 2016; 12 (6): 785-786.

33. Kosticova M, Dankulincova V, Madarasova Geckova A. Polovica 15-rocnych adolescentov spi menej akoby mala: vysledky HBSC studie Slovensko 2017/2018. 119-126. In: Hudeckova H, Jakusova V, Svihrova V, Baska T (Eds). Aktualne problemy verejneho zdravotnictva vo vyskume a praxi IV. Martin: Jesseniova lekarska fakulta Univerzity Komenskeho v Martine, 2019.
34. Ginter E, Simko V. Becoming overweight: is there a health risk? Bratisl Lek Listy 2014; 115 (9): 527-531.

35. Neermark S, Holst C, Bisgaard T, Bay-Nielsen M, Becker U, Tolstrup JS. Validation and calibration of self-reported height and weight in the Danish Health Examination Survey. Eur J Public Health 2019; 29 (2): 291-296.

36. Cespedes Feliciano EM, Quante M, Rifas-Shiman SL, Redline S, Oken E, Taveras EM. Objective Sleep Characteristics and Cardiometabolic Health in Young Adolescents. Pediatrics 2018; 142 (1): e20174085.

37. Jong-Hyuck K, Wi-Young S. Association of smoking frequency and cigarette consumption with obesity in Korean adolescents. Bratisl Lek Listy 2012; 113 (10): 599-603.

38. Babjakova J, Vondrova D, Vohnout B. Nutricne strategie pri redukcii telesnej hmotnosti. 10-19. In: Belovicova M, Vansac P (Eds). Zbornik prispevkov Dni praktickej obezitologie a metabolickeho syndromu. Varsava: Wyzsza Szkola Finansow i Zarzadzania w Warszawie, 2018.

39. Moradi F, Imani AR, Faghihi M. Effects of regular exercise plus food restriction on left ventricular pathological remodeling in heart failure-induced rats. Bratisl Lek Listy 2019; 120 (4): 243-248.

40. Hujova Z, Lesniakova M. Anthropometric risk factors of atherosclerosis: differences between urban and rural east-Slovakian children and adolescents. Bratisl Lek Listy 2011; 112 (9): 491-496.

41. Schusterova I, Jurko A, Minarik M. Left ventricular systolic and diastolic function in children with overweight and obesity. Bratisl Lek Listy 2013; 114 (9): 526-530.

42. Cabre-Riera A, Torrent M, Donaire-Gonzalez D, Vrijheid M, Cardis E, Guxens M. Telecommunication devices use, screen time and sleep in adolescents. Environ Res 2019; 171: 341-347.

Received June 28, 2019. Accepted July 10, 2019. 